\title{
A SOCIO-ECONOMIC PROFILE OF THE UNORGANIZED DAIRY FARMERS
}

\author{
D. H. RAM ${ }^{1}$, RAJESH KUMAR ${ }^{2}$, G. M. CHAUDHARI ${ }^{3}$, \\ S. J. VEKARIYA ${ }^{4} \&$ H. H. SAVSANI ${ }^{5}$ \\ ${ }^{I}$ Ex-MVSc Scholar, Department of Veterinary Extension, Veterinary College, Junagadh Agricultural University, \\ Junagadh, Gujarat, India \\ ${ }^{2}$ Assistant Professor, Department of Veterinary \& A. H. Extension Education, College of Veterinary Sciences, \\ LUVAS, Hisar, Haryana, India \\ ${ }^{3}$ Assistant Professor, Department of Veterinary Extension, Veterinary College, Junagadh Agricultural University, \\ Junagadh, Gujarat, India \\ ${ }^{4}$ Assistant Professor, Kamdhenu University, Gujarat, India \\ ${ }^{5}$ Associate Professor, Department of Animal Nutrition, Junagadh Agricultural University, Junagadh, Gujarat, India
}

\begin{abstract}
Dairying has become an important secondary source of income for millions of rural families and has assumed the most important role in providing employment and income generating opportunities particularly for marginal and women farmers. To access the socio-economic status of unorganized dairy farmers the study was carried out in Junagadh district of Gujarat state. The multistage sampling method was used for the study. Total two hundred samples were taken from randomly selected two talukas of Junagadh district of South Saurashtra region. The results of the social status indicated that the majority (62.5 per cent) of the farmers were from the middle age group, were educated up to primary level, had the nuclear type of families and agriculture and animal husbandry as the major occupation while economic status revealed that majority of unorganized dairy farmers belonged to low level of income ( $<253000$ rupees) group and had medium size land holding. The majority (65.50\%) of the farmers used media sources of information for obtaining information about dairy farming, and had medium experience.
\end{abstract}

KEYWORDS: Income, Socio-Economic Status, Social Participation \& Unorganized Dairy Farmer

Received: Aug 11, 2018; Accepted: Sep 01, 2018; Published: Sep 17, 2018; Paper Id.: IJASROCT20187

\section{INTRODUCTION}

India is the highest milk producer in the world with a total volume of 132.4 million tons. India is predominantly an agrarian economy with more than 75 per cent of its population living in villages and depending on agriculture and allied activities for their livelihood. Dairying has become an important secondary source of income for millions of rural families and has assumed the most important role in providing employment and income generating opportunities particularly for marginal and women farmers. In our country most of the milk is produced by small, marginal farmers and landless labourers. In terms of actual number, marginal farmers and landless laborers form the largest group of rural milk producers (Himabindu et al., 2014). Majority of landless laborers, marginal and small farmers are holding small scale dairy farming keeping less than 10 animals and struggling for sustaining their livelihood on few numbers of dairy animals in rural areas. Key feature of the Indian dairy industry is still predominantly unorganized and of the total milk produced in India, only 18-20 per cent is channelized through the organized segment (Anonymous, 2014). Because of larger participation of landless 
labourers, marginal farmers and small farmers in unorganized small scale dairy farming, it is the need to identify their socio-economic profile so that right approach can be formulated for their social and economic development.

\section{MATERIALS AND METHODS}

The present study was carried out in Junagadh district of Gujarat state. Two talukas were selected randomly for the study purpose. From each selected taluka, ten villages were selected randomly. Thus, the study was confined to total twenty selected villages in Junagadh district. Ten unorganized dairy farmers having not more than ten numbers of dairy cows or buffaloes were selected randomly from each village. Thus, a random sample of 200 unorganized dairy farmers was selected for the study. The multistage sampling method was used for the present study. The personal interview technique was used as a tool through which first-hand information was collected. The semi-structured interview schedule was prepared by keeping in view the objectives of the study. Before collection of data, interview schedule was pre-tested by the interviewer. The collected data were compiled, tabulated and analyzed to interpret the results. The descriptive statistics like frequency, percentage and range were used for the investigation.

\section{RESULTS AND DISCUSSIONS}

\section{Social and Economic Characteristics of Unorganized Dairy farmers}

Age group of unorganized dairy farmers revealed that the majority $(62.50 \%)$ of the farmers belonged to middle age group followed by 21.00 per cent with old age and 16.50 per cent were from a young age group. Similar finding was reported by Nishi et al., 2011. Educational status revealed that the majority of the respondents (55.00\%) had primary, secondary or higher secondary level of education. This may be due to the availability of primary school and secondary school at village level and higher secondary school at nearby villages.

The economic status indicated by annual income depicts that the majority $(65.50 \%)$ of the farmers belonged to low level of income (<253000 rupees) group, whereas 33.65 per cent of farmers had medium level of income (253000426000 rupees) and only one per cent farmers hada high level of income (>426000 rupees) group. The probable reason could be that most of the rural farm families belonged from lower to middle class and their main source of income based on agriculture and animal husbandry. Land holding by the families of the farmers indicates that majority (37.50\%) of the farmers respondents had medium size land holding followed by 27.50 per cent landless farmers, 25.50 per cent with small land holding and 5 per cent with marginal land. Only 4.50 per cent of the respondents were in large farmer's category i.e. with land holding above 4.00 hectares. Occupational status indicates that majority $(64.00 \%)$ of farmers had major occupation of animal husbandry along with agriculture, $20.00 \%$ were performing only animal husbandry occupation and $16.00 \%$ were performing animal husbandry along with agriculture and agriculture related activities(Kumar et al., 2011).

The majority $(89.00 \%)$ of the unorganized farmers belonged to the nuclear type of families and 11.00 per cent of them belonged to joint type of families (De et al. 2014) whereas family size revealed that the majority $(78.50 \%)$ of the farmers belonged to the medium sized families i.e. 5 to 6 members, while 11 per cent of them belonged to large sized families having more than 6 members and only 10.50 per cent of the farmers belonged to small sized families having up to 4 members. This may be due to the thought of more head might impart more work and thus generate more income to family (Raval and Chandawat, 2011).

Social participation in different social activities definitely influences one's way of thinking, acting and behaving. It can be inferred from the table that majority of the respondents had low and medium level of social participation. Because 
few villages had milk co-operative societies and others villages had no co-operative society (Rathod et al., 2011). Dairy farming experience indicates that 63.50 per cent of the respondents had medium experience followed by 19.50 per cent with a low level and 17.00 per cent had a high level of experience in dairy farming (Bashir et al., 2011).

Table 1: Socio-Economic Profile of Unorganized Dairy Farmers ( $n=200)$

\begin{tabular}{|c|c|c|c|}
\hline Characteristics & Category & Frequency & Percentage \\
\hline \multirow{3}{*}{ 1. Age } & Young age (below 39 years) & 33 & 16.5 \\
\hline & Middle age (39 to 55 years) & 125 & 62.5 \\
\hline & Old age (Above 55 years) & 42 & 21 \\
\hline \multirow{5}{*}{ 2. Education } & Illiterate & 89 & 44.5 \\
\hline & Primary (up to $8^{\text {th }}$ std.) & 64 & 32 \\
\hline & Secondary $\left(9^{\text {th }}\right.$ to $10^{\text {th }}$ std. $)$ & 24 & 12 \\
\hline & Higher Secondary $\left(11^{\text {th }}\right.$ to $\left.12^{\text {th }}\right)$ & 22 & 11 \\
\hline & Graduate & 1 & 0.5 \\
\hline \multirow{3}{*}{ 3. Annual income } & Low(Up to Rs.2,53,000) & 131 & 65.5 \\
\hline & Medium (Rs. 253001-426000) & 67 & 33.5 \\
\hline & High (Above Rs. 4,26,000) & 2 & 1 \\
\hline \multirow{2}{*}{ 4. Type of family } & Joint & 22 & 11 \\
\hline & Nuclear & 178 & 89 \\
\hline \multirow{3}{*}{ 5. Size of family } & Small (Up to 4 members) & 21 & 10.5 \\
\hline & Medium (5 to 6 members) & 157 & 78.5 \\
\hline & Large (> 6 members) & 52 & 11 \\
\hline \multirow{5}{*}{ 6. Land holding } & Landless & 55 & 27.5 \\
\hline & Marginal (Up to 1 ha.) & 10 & 5 \\
\hline & Small (1.01to 2 ha.) & 51 & 25.5 \\
\hline & Medium (2.01 to 4 ha.) & 75 & 37.5 \\
\hline & Large (above 4 ha.) & 9 & 4.5 \\
\hline \multirow{3}{*}{ 7. Occupation } & Animal Husbandry (A. H.) & 40 & 20 \\
\hline & A. H. + Agriculture & 128 & 64 \\
\hline & $\begin{array}{l}\text { A. H. + Agriculture + Agriculture } \\
\text { related activities }\end{array}$ & 32 & 16 \\
\hline \multirow{3}{*}{ 8. Social participation } & Low & 160 & 80 \\
\hline & Medium & 30 & 15 \\
\hline & High & 10 & 5 \\
\hline \multirow{3}{*}{$\begin{array}{l}\text { 9. Experience in dairy } \\
\text { farming }\end{array}$} & Low (Up to 27 years) & 39 & 19.5 \\
\hline & Medium (28 to 44 years) & 127 & 63.5 \\
\hline & High (More than 44 years) & 34 & 17 \\
\hline \multirow{3}{*}{ 10. Sources of information } & Less used ( $<9$ score $)$ & 40 & 20 \\
\hline & Medium used (10 to 12 score) & 131 & 65.5 \\
\hline & More used (>13 score) & 29 & 14.5 \\
\hline \multirow{3}{*}{ 11. Herd size } & Small size (Up to 4 animals) & 124 & 62 \\
\hline & Medium size (5 to 7 animals) & 49 & 24.5 \\
\hline & Large size (> 7 animals) & 27 & 13.5 \\
\hline \multirow{3}{*}{ 12. Daily milk production } & Low (Up to 13 litre) & 124 & 62.0 \\
\hline & Medium (14 to 16 litre) & 57 & 28.5 \\
\hline & High (More than 16 litre) & 19 & 9.5 \\
\hline \multirow{3}{*}{ 13. Extension participation } & Low (11.47 to 18.75$)$ & 6 & 3 \\
\hline & Medium (18.76 to 26.03) & 172 & 86 \\
\hline & High (26.04 to 33.31) & 22 & 11 \\
\hline
\end{tabular}

Sources of information for obtaining information pertaining to animal husbandry practices indicated that the majority $(65.50 \%)$ of the farmers used medium level for obtaining information about dairy farming, whereas 20.00 per cent and 14.50 per cent used less and more sources of information, respectively(Raval and Chandawat, 2011). The extent 
of contact of a farmer with different extension agencies and their participation in various extension activities reveals that 86 per cent farmers had a medium level of extension participation followed by 11.00 per cent had high level and 3.00 per cent had low level of extension participation.

Herd size shows that more than half of the $(62.00 \%)$ of the farmers had a small number of herd size followed by 24.50 per cent had medium herd size. It was observed that the majority of farmers had medium size land which makes them difficult to maintain the large herd size of milch animals (Jaisridhar et al., 2013).

Daily milk production shows that more than half of the $(62.00 \%)$ of the farmers had a low level of milk yield followed by 28.50 per cent had a medium level of milk yield while 9.50 per cent of them had a high milk yield. It was found interesting that none of the unorganized dairy farmer had availed the benefit of dairy scheme run by the government. It might be due to the farmers rearing low producing animals and also less awareness about such dairy development schemes.

\section{CONCLUSIONS}

Unorganized dairy farmers had medium level of experience of practicing animal husbandry, used medium sources of information and had small size of the herd. Socio-economic parameters of the unorganized dairy farmers revealed that there is a scope for further improvement in the socio-economic status, which ultimately leads to the development of the society in general and dairy farmers in particular.

\section{REFERENCES}

1. Himabindu, T., Suibrymanyam, S. E. V. and Bhat, M. S. (2014). SWOT analysis of dairy industry in India. International Journal of Scientific Research, 3(1): 249-251.

2. Anonymous (2014). Indian Dairy industry is still predominantly unorganized: Ashutosh Maheshwari, CEO, Motilal Oswal Investment Advisors. E-News Paper- The Economic Times.

3. Nishi, A., Sah, K. and Ram, K. (2011). Dairy farmers' satisfaction with dairy cooperative societies: a case study. Indian Research Journal of Extension Education, 11(1): 74-78.

4. Kumar, V., Prajapati, R. S., Ghintala, A. and Singh, K. (2011). Source and channels of agriculture information used by the beneficiary farmers of NAIP-III. Gujarat Journal of Extension Education, 24: 35-38: (2013).

5. De, A., Goswami, A. and Mazumder, D. (2014). Demographic profile and distribution of livestock farmers according to knowledge and awareness level in Institute Village Linkage Programme. International Journal of Current Microbiology Applied Sciences, 3(7): 378-384.

6. Raval, R. J. and Chandawat, M. S. (2011). Extent of knowledge of improved animal husbandry practices and socio-economical characteristics of dairy farmers of district Kheda, Gujarat. International Journal of Farm Sciences, 1(2): 129-137.

7. Rathod, P. K., Landge, S., Nikam, T. R. and Vajreshwari, S. (2011). Socio-personal profile and constraints of dairy farmers. Karnataka Journal of Agricultural Science, 24(4): 619-621.

8. Bashir, B. P., Rajkamal, P. J., George, R. P., Rajeev, T. S. and Mercey, K. A. (2011). Socio-personal profile of tribal livestock farmers in relation to degree of belief and extent of adoption of selected indigenous animal husbandry practices. Journal of Indian Veterinary Association, 9(2): 16-20. 
9. Jaisridhar, P., Sankhala, G., Kadian, K. S., Kumar, S. and Sangeetha, S. (2013). Factors determining adoption of scientific dairy farming with special reference to farmer's call centre of Tamilnadu. Pakistan Journal of Agricultural Science, 50(4): 549-553.

10. Kankarne, Y. O. G. E. S. H. W. A. R., Siddiqui, F. A. H. E. E. M., \& Kochewad, S. A. N. J. I. V. K. U. M. A. R. (2017). Effect of socio-economic traits on the level of knowledge of dairy farmers. International Journal of Agricultural Science and Research, 7(1), 287-292. 
